\title{
Collective economic actors
}

\section{Greg Urban}

A case can be made that the for-profit business corporation is the central institution of the modern capitalist economic system. Stock exchanges, another key institution, presuppose the existence of companies with share-holders. It is true that shares in collective ventures antedate the development of the great jointstock companies of the seventeenth century, which formed the legal models for the publicly traded corporation from the nineteenth century onwards (Licht 2014: $145 \mathrm{ff}$.). A deed for transfer of shares in the Swedish copper mining company at Stora Kopparberg (Great Copper Mountain), for example, was issued in 1288 (Business Historical Society 1929: 7-8; Rydberg 1979: 12-13). Still, formation of the joint-stock companies of the seventeenth century, such as the English East India Company (later the British East India Company) and the Dutch East India Company, accelerated the growth and expansion of stock exchanges, along with the financial systems and occasional speculative fever associated with them. Hence, the corporation as cultural form is arguably an essential component, possibly the essential one, of modern capitalism. Yet it has until recently received relatively little ethnographic or theoretical scrutiny within anthropology (exceptions include Foster 2017; Urban and Koh 2013).

Looked at from an anthropological point of view, the economically productive corporation is a social group. It can be studied not just as the manifestation of a legal concept, although it is that in some measure, nor just as a voluntary association of individual rational economic actors, although it is that in some measure as well. It can also be seen as a collectivity, indeed, as a culture-bearing social group. It is amenable to the kind of anthropological research done in small- and mediumscale societies and local communities, although global corporations often require multi-sited research (e.g. Garsten 1994; Oliveira 2013; Røyrvik 2013; Stull 2017). The possibility of using anthropological research from community ethnographies to understand corporations did not escape the attention of popular business writers (Deal and Kennedy 1982; see also Ouchi 1981; Pascale and Athos 1981). Still, recognition of the communal character of corporations failed to produce substantial new theorisation within anthropology, despite the growth of business anthropology and its in-depth ethnographies (e.g. Ho 2009; Krause-Jensen 2010).

From an anthropological perspective, the for-profit business corporation (hereinafter 'business corporation'), publicly traded or not, can be seen as a communal 
form onto which has been grafted a legal form. Evidence for this view can be found in the historical record. The joint-stock companies of seventeenth-century Europe grew out of the earlier medieval corporation, which was the legal form of towns, guilds, monasteries and universities (Davis 2000 [1905]). Eli Heckscheler (1934: volume 1, 397, quoted in Eklund and Tollison 1980: 718) observed: 'In the joint stock companies, too, the members were "brethren" ... just like the members of the innumerable medieval corporations, including the municipalities.' A key characteristic of the economic organisations out of which the later companies developed is their family or family-like basis. This is in keeping with Max Weber's (1968 [1925]: 375-84) argument that capitalist forms of economic organisation, including the great joint-stock companies, grew out of the decline of the household as the principal economically productive unit. Of early capitalist partnerships, such as the maritime firm (societas maris) and the commenda that gave rise to the idea of limited liability that is characteristic of modern corporations, Fernand Braudel (1982: 438) remarked: 'It is worth insisting on the family or near-family atmosphere which characterised them (even when there was no actual family concerned).' Many, even most, small privately held corporations in the US today continue to be based on families or operate in a family-like manner, including some that I have had the opportunity to get to know first-hand.

One key goal for future research in economic anthropology should be the ethnographic analysis and theorisation of the communal character of modern business corporations, including those of the large publicly traded variety. Development of that research agenda will be the main focus of this chapter. The internal cultural processes and patterns of other collective actors, including regulatory bodies such as central banks (Holmes 2009) and advisory organisations like the World Economic Forum at Davos (Garsten and Sörbom 2019), are also necessary for attempts to advance an anthropological understanding of modern capitalism.

In this chapter, I put forth a series of questions that are designed to articulate an anthropological agenda for research on business corporations and other collective economic actors. In what measure are companies internally organised around market (versus communal) principles? To what extent does the profit motive suppress other considerations inside the corporation and other collective actors? How do laws pertaining to the corporate form affect the productive potential of a company as well as communal well-being both inside and outside the productive group? What role does diffusion, in addition to internal transmission, play in shaping corporations and their products as cultural forms?

\section{Market versus communal principles}

Perhaps the most fundamental question anthropologists can ask about business corporations is why they exist. The normative variant would be: should they exist, and if so in what form? Since those questions have been asked and answered in different ways in other disciplines and intellectual traditions, a starting point for 
providing an anthropological answer is to probe the differences between an anthropological approach, oriented to culture and ethnographic research, and others. In this section, I begin with the most obvious starting point, the view from economics.

With its conceptualisation of the economy as consisting of rational individual human beings engaged in self-interested transactions with one another, the existence of collective actors as culture-bearing social groups seems to make little sense. At least, this was the view of Ronald Coase (1937), who posed the question of why firms exist. Coase took as his point of departure what today is known as the efficient-market hypothesis, the idea that market transactions are the best way to price assets. The idea is often associated with Eugene Fama's (1965) research on the pricing of stocks, but it has deep roots in economic thought, its outlines discernible perhaps even in Adam Smith's (1994 [1776]: 485) invisible hand, the idea that individuals engaged in self-interested activity often end up promoting collective interest more effectively than if they consciously tried to do so. From this vantage point, one might well ask why we need corporations. Would it not be better if production were carried out through individuals transacting with one another, rather than through corporate communities? As Coase (1937: 387) noted of the economic thought of his time, 'It is often considered to be an objection to economic planning that it merely tries to do what is already done by the price mechanism.'

Anthropologists will recognise in this line of reasoning the concept of neoliberalism, to which so much scholarly attention has been devoted in the past quartercentury (Harvey 2005). The concept as understood within anthropology, according to Tejaswini Ganti (2014: 91), refers to both a structural force within capitalism and an ideology. As a normative position, neoliberalism asserts that it is desirable that all of social life should be made to resemble market-like transactions. Hence, the role of government should be minimised and governmental functions privatised insofar as is possible. Here we find an ideological position compatible with the objection to economic planning observed by Coase among his colleagues. While much research has been done within anthropology on neoliberalism as a structural phenomenon and also on government policies and procedures, as well as NGOs, bureaucrats and even media representations (Ganti 2014), little ethnographic research has focused on the inner workings of corporations. Indeed, the word 'corporation' is absent altogether from Ganti's review of the anthropological literature on neoliberalism. In what measure do company boards, managers and employees espouse neoliberal ideas and ideals? How aware are they of such ideals? In what ways are they affected by the circulation of neoliberal ideology or by the structural forces of neoliberalism? These are questions ripe for ethnographic investigation.

Coase, however, was not concerned with normative matters. Rather, he was preoccupied with economic theory, especially a blind spot in it. That is, the theory concerns itself with transactions between self-interested individuals while ignoring the empirical existence of collective actors (companies or firms) as key market players. So, his question was: why should such collective actors exist? Could their 
existence be explained from within economic theory? His efforts, that is, were directed at shoring up economic theory, not undermining it.

The explanation that he proposed is that transactions are not free but are costly. A moment's reflection reveals how unrealistic it would be to think that complex production tasks would arise spontaneously out of transactions where individuals could choose to negotiate every aspect of the work involved. How much will you pay me to flip this switch, call this individual, write this report? Production would bog down in transactional negotiation, if it ever started in the first place. As Coase (1937: 390-91) put it, 'The costs of negotiating and concluding a separate contract for each exchange transaction which takes place on a market must also be taken into account.' Hence, his solution: firms exist to reduce transaction costs.

The solution contains a significant insight that opened up economic research on a range of issues, such as the conditions under which firms tend to be larger or smaller. Importantly also, the insight gave birth to the New Institutional Economics, which has been influential especially in economic history (North 1990; North and Thomas 1973). This development has stimulated some anthropologists, such as Jean Ensminger (1990, 1992) and David Guillet (2001), while being roundly criticised by others, such as F.G. Bailey (2003: esp. chapter 2). Still, virtually nothing in the way of ethnographic research within corporations deals with such transactional issues.

The idea that firms reduce transaction costs allows economic theory to make sense of the existence of corporations. Simultaneously, it provides an opening for anthropological theory, for it allows us to ask about the kinds of situations that might lead people not to treat tasks and interactions as market negotiations. An obvious answer would be in communal endeavours. People work together to accomplish a common goal. Indeed, in many instances it is not even a question of working together towards a goal, but simply of being together with others. In short, it is possible to treat firms or enterprises, whether legally registered as corporations or not, as communities, even if communities of a peculiar sort. What light can anthropological theory shed on business corporations as communities?

In her doctoral research, Madeline Boyer (2018) found that for some people at least, working together, or rather working in the presence of others with whom they interact, is preferable to working alone. These people want to be part of a working community. Boyer did a long-term ethnographic study of co-working spaces. Those are places in which people who might otherwise be working alone consultants, individual entrepreneurs or those who are required or allowed to work away from their employers' premises - choose to work in a space along with others, even though they may be working towards entirely different and unrelated economic ends. Co-working spaces are part of a worldwide movement and, as Boyer (2018: 19) explains, they are distinct from 'business incubators and accelerators, hackerspaces and makerspaces, office parks, and corporate office-sharing'. They are different in at least one important respect: their main goal is to build community. In 
co-working spaces, 'financial sustainability' is largely 'a means to an end rather than the end itself' (2018: 21).

Arguably, Boyer's research confirms what business anthropologists have been finding over the past several decades. Even business corporations can be viewed as operating in some measure in accord with communal principles. Life within corporations is not only built around work. In addition, it is built around rituals, including the ritual elements of meetings (Kunda 1995; Sandler and Thedvall 2017; Schwartzman 1989) and workshops (Wilf 2015), around symbols such as corporate motivational videos (Urban 2015), myths and other narratives (including their role in anchoring legitimacy, Ho 2009), around constructing gendered identities (Fisher 2012) and around transmitting information (Orr 1996) (for a broader review, see Urban and Koh 2013). Much ethnographic work waits to be done in these areas. The principal question to be explored is: what is social life like inside of firms and other collective economic groupings? In particular, how does social life articulate with economic interest?

At the same time, anthropologists should not lose sight of the fact that business corporations are also necessarily about economics. Although Coase saw himself as solving a problem within economic theory, Michel Callon (1998: 2) proposes that 'economics, in the broad sense of the term, performs, shapes and formats the economy, rather than observing how it functions'. While he may overstate the point, the empirical question remains of the degree to which corporations are organised around economic principles and around communal and other principles. Ethnographic research is needed to determine the extent to which economics infuses talk inside the firm and other collective economic entities, and especially what kind of economics talk gets circulated, since economic theory changes, is contested and is subject to some extent to fad-like enthusiasms.

\section{Profit versus other considerations}

The starting point for thinking about business corporations is entirely different within political economy. Rather than individual rational actors engaged in market transactions and maximisation, for Marx the starting point for the analysis of existing societies was the mode of production, especially the relationship between classes. For Marxists, the business corporation is primarily the place where capitalists are pitted against workers and the central relationship is one of exploitation. Malcolm Dunn (1992: 193), in launching his critique of Coase, quotes Eva Bössman (1981: 667) to the effect that political economists 'presuppose the existence of "economic units", be these households or enterprises, as self-evident'. They require 'no further economic explanation'. Put differently, we might say that the political economist focuses on the broader social relationships in which businesses operate. Consequently, the question asked by Coase of why firms exist does not even arise. Business enterprises are a product of class relations and are the key mechanism through which one class exploits another. 
The difference between the orientations of political economy and economics is important not only because of the taken-for-granted status of the firm within political economy. It is important, too, because Coase's formulation purports to derive hierarchical social relations within the firm from the costs associated with forming longer-term contracts with employees versus the costs associated with transacting in the marketplace. In contrast, political economy, and Dunn (1992) in particular, wants to derive the internal hierarchical relations within firms from the external power relations within society. That is, political economy, following Marx, wants exploitative class relations to be seen as the driving force behind those internal relations, with labour denied its proper reward.

In contrast with both economics and political economy, a genuinely anthropological approach to the social relations within firms, and other collective economic entities, would be one grounded in culture. Especially when it comes to productive units such as business corporations and other firms, an anthropological approach directs attention to the culture within the organisation, as well as to the relationship between the organisation's culture and the larger culture outside of it. The relationship between these two cultures has been a focus of business-anthropological research for some time. Examples include the classic monograph by Choong Soon Kim (1992) on the South Korean Poongsan Corporation, including the role of Confucianism within it; Tamoko Hamada's (1991) work on Japanese-American joint ventures, where the differing cultural orientations to management come into focus; and accounts of McDonald's in East Asia (Watson 1997).

The theoretical agenda for an anthropological perspective on culture may be differentiated from that of economics and political economy, in fact, by looking at inside-outside relations. For the economist, Coase in particular, the relation is defined as firm versus market, resting on the point that it would be unrealistic to try to carry out production only through market-based transactions. For the political economist, Dunn in particular, the issue is the power relations in the broader society, especially class relations, and their role in shaping processes within the firm, which itself is taken as given. From the perspective developed in business anthropology, the focus is on the relationship between the culture inside the firm and the culture outside of it, including the culture of other firms, a relationship that is reciprocal and that results in a mutual shaping. Implicit in this is the point that the boundaries of the firm are both created and traversed, a key feature of a distinctive anthropological approach to business.

Indeed, the creation, maintenance and crossing of the boundaries around enterprises may prove the key to the future development of an anthropological theory of collective economic actors. Enterprises must be analysed in terms of their genesis and internal cultural transformations over time, as well as in terms of their relations to external culture, including surrounding rules and laws, as well as broader circulating views of their role in social life. Collective economic actors develop internally as entities in their own right, as culture-bearing social groups. In some cases, African or Native American social groups transform in the direction of 
business enterprises (Comaroff and Comaroff 2009), as has happened during the recent neoliberal period. An example from the US in the nineteenth century is the Oneida community in New York State, which changed from a religious experiment in communal living into a joint-stock company (Cooper 1987). Other enterprises germinate out of invention and innovation, guided by entrepreneurship, or by finding a niche not yet served by existing firms. In any case, the culture of each business enterprise tends to be in some measure distinct, while also resembling that of other corporations. One goal for future ethnographic research in economic anthropology ought to be to chart the nature and distinctiveness of firms' cultures and the processes of internal transformation that produce them.

Here the possibility of more far-reaching theoretical development emerges. The concept of business enterprises taking shape as social groups characterised by internal cultures suggests a refinement of the labour theory of value associated with Marx and political economy (Urban 2016: 324-27). In that theory, enterprises generate profit through exploitation of workers, where the value of commodities on the market results from the labour time that has gone into them. This is presumed to be true whether we are dealing with tangible objects such as clothing and automobiles or the less tangible, such as financial instruments or skills and know-how (as, for example, in the case of medical services). The idea of a firm's internal culture suggests that commodities are produced not via labour time alone, but by culturally guided activity. That culture is one source, albeit not the only source, of value. The culture of business firms takes place first and foremost around the socially transmittable learning contained within them that is necessary for the production of marketable commodities. In this view commodities are, in effect, congealed culture.

In the case of business corporations, a key part of that congealed culture is the firm's internal culture. There are two key ways in which the distinctive culture within a given enterprise matters: it can manifest itself in the commodity produced, resulting in a product that is perceived to be distinctive, or it can manifest itself in the processes through which it is produced. Where the distinctiveness of the commodity makes little or no difference there is effectively nothing of what Edward Chamberlin (1933: $71 \mathrm{ff}$.) called 'product differentiation'. In this case the cost efficiency of its production, based on the internal culture of the company, becomes a deciding factor in the competitive market. In this situation, Marx's argument becomes relevant. That is because one way to lower production costs is to pay employees less, and Marx (1990 [1867]: 797-99) holds that in capitalist systems there is inevitably pressure to lower wages, resulting in the immiseration of the working class. (The extent to which business corporations and other enterprises necessarily succumb to the immiserating forces of domination Marx described is, of course, an empirical matter.)

A task for economic anthropology, therefore, is to assess the circulating worldviews within enterprises as culture-bearing communities. Does profit in fact trump all other considerations, even if it can be achieved only at the expense of employee 
or customer well-being? Alternatively, to what degree do firms focus on making commodities that potential customers need and want? How much consideration is given to the well-being of employees and customers or of broader polities, including the country? Are there other goals? My own experience suggests that differing worldviews compete with one another within any given large corporation.

\section{Effects of laws about the corporate form}

It is important to distinguish between the anthropological corporation (clasically Maine 1917 [1861]; also Fortes 1969; Radcliffe-Brown 1952) and the legal corporation (Urban 2016). The former is a culture-bearing social group; the latter is an abstract legal fiction. It is important for anthropologists to make this distinction, since they often assume that 'corporation' refers to a social group when it is used in its legal sense. In many countries one individual can create and own many legal corporations, each of which is a fictitious entity rather than a social group and none needs have any relationship to a social group. A key task for anthropology is to tease the two concepts apart, in order to encourage lawyers, economists, politicians and the general public to use the anthropological concept as the measure in reasoning about the legal concept. Doing so could bring about a shift in orientation to corporations.

John Davis (2000 [1905]: volume II, 215 n1), in his comprehensive survey of the corporation since the early Middle Ages in Europe, concludes: 'The analogy, in legal contemplation, between a family and a corporation seems to have been discovered by Sir Henry Sumner Maine.' An example of the corporation that Maine (1917 [1861]) used, which was taken up by later anthropologists, is the clan, a social group that could live on despite the death of its individual members. As Maine (1917 [1861]: 76) put it, 'corporations never die'. For him, as for later anthropologists, what made a social group a corporation is this temporal durability. That quality gives the clan a substance that resonates with the legal notion, especially as it developed in the late nineteenth and early twentieth centuries in the US.

Reflecting upon a collection of papers concerned with corporate personhood, Ira Bashkow (2014: 296) grapples with the theory of the corporation from the perspective of the classic e pluribus unum problem that has informed so much of the anthropological theorising of community: 'How does a collectivity, comprising numerous individuals, come to count as but one?' Bashkow appropriately focuses on the anthropological corporation, though he is aware of the legal corporation, which he tends to dismiss: 'how could such an awesome feat - the creation of an artificial person - be accomplished by the mere filing of a simple form, the "articles of incorporation"?' (2014: 297). From the perspective of the anthropological corporation he is right to pose this question, yet numerous legal corporations are created every day by such performative acts. Understanding the contribution of the legal corporation to the anthropological one is crucial to both our ethnographic and our theoretical task. 
As a thought experiment, we might contemplate what the effect would be of subtracting the legal from the anthropological corporation. We would still have the productive community, with its internally circulating culture of know-how, beliefs, values, rituals and the like. The e pluribus unum question would remain, but something important would be missing. Take, for example, the case of the tobacco industry that Peter Benson (2014) discusses in the collection on which Bashkow comments. Regarding the industry's participation in campaigns to prevent 'the illegal sale of tobacco to underage purchasers', Bashkow (2014: 298) observes: 'What drops away in all these campaigns is the coercive nature of addiction and the industry's role in promoting it.' Fair enough. At the same time, however, we might ask what would happen if it were illegal to produce and sell tobacco. The situation could well resemble the era of Prohibition in the US, when making and selling alcohol were illegal. Because they were illegal, the government lacked the ability to set quality standards for what those who wanted alcohol were drinking. That is because the legal part of the anthropological corporation subjects such corporations to legislation and the courts. The company could be sued if it failed to comply with government regulations. And in being subjected to the law, legal corporations are subject to collective supervision. Theorisation of the business corporation as an anthropological entity, then, must take account of its existence as a legal entity.

Taking that legal side into account is likely to be done best by business anthropologists who, as employees or consultants, have an insider's view of the corporation, ideally in legal departments and grappling with the kinds of issues with which business enterprises must deal. Anthropological researchers in such positions would be able to develop answers to important questions. Do corporations see laws simply as external obstacles to be negotiated in the pursuit of profit, as some of the recent legal scandals involving corporations suggest? Are those laws seen as resources? In what measure and for what purposes do anthropological corporations, as collective actors, employ fictive legal corporations? In what measure and under what circumstances do corporate leaders see themselves as contributing to broader societal goals, where complying with national laws may be viewed as part of good citizenship, as opposed to seeing their organisations as independent of any national polity?

\section{The roles of diffusion and internal transmission}

A key factor in theorising modern business corporations is the ease with which the internal culture and the products of an organisation can be copied (Urban 2016: 330-36). A good ethnographic account of such copying is Michael Prentice's (2015) insider's description of a Korean firm in which individuals regularly borrowed documents, such as PowerPoint presentations, from other firms, modifying the traits that were characteristic of the source firm. There is a dearth of ethnographic accounts of corporate diffusion, though a fair amount of research on the topic has been done based on externally accessible data. An example of such work is by N. Venkatraman, Lawrence Loh and Jeongsuk Koh (1994), who look at the diffusion 
of organisational structures and the spread of joint ventures, or Ilir Haxhi and Hans van Ees (2010), who study the diffusion of codes of good corporate governance. The bulk of these studies have come out of business schools. Many other business anthropologists, myself included, have observed the critical role consultants play in such diffusion, especially the major consulting firms, which spread organisational ideas from company to company.

Such studies have demonstrated that corporations as social groups have internal cultures that can be copied by other corporations. However, corporations are also producers of culture. The idea of the commodity as congealed culture discussed earlier modifies the political-economic labour theory of value, in which commodities are 'quantities of congealed labour-time' (Marx 1990 [1867]: 130). In that theory, the amount of labour time that goes into producing a commodity accounts for its exchange value, which means that any profit taken out of the market price of the commodity comes at the expense of labour. In the commodity-as-culture approach, in contrast, the question is what forces drive the movement of the commoditised culture, and a critical force appears to be people's interest in the culture that the commodity carries: in the language of economic theory, demand. It is that interest that requires detailed anthropological investigation (see Wilk and Arnould 2016), since the culture carried by the commodity ultimately articulates with the broader culture in which the commodity circulates.

From the point of view of diffusion, another key consideration for anthropological theory is that commodities as congealed culture also participate in inter-corporate copying. This is crucial because the possibility of making a profit depends on the corporation's ability to capture the cultural flow. In other words, in order to realise a profit a corporation must be able to satisfy an interest in or demand for the commodity as culture that is not met by the commodities of other corporations. One way it can do so, as postulated in Marx's theory, is by paying workers less, for example by outsourcing and thereby lowering the cost of production, but this is only one way. Additionally, it can do so by providing what other corporations do not. This happens when there is sufficient interest in the corporation's commodity that customers are willing to pay more than the cost of its production, whether the commodity is desirable because of some aspects of the corporation's internal culture that cannot be readily copied or because of the corporation's control over some necessary constituent of the desired commodity. Many corporations endeavour to make their commodities distinctive and desirable by cultivating loyal followings through brands (Foster 2014; Manning 2010). Without such distinctiveness the desire for profit, to the extent that it is unchecked by other motives, will tend to force employee compensation down, as the labour theory of value implies.

Put differently, corporations can produce profit without exploiting employees by capturing a cultural flow, by having desirable commodities that other corporations cannot produce. This possibility seemingly stands in direct opposition to the ease with which commodities can be copied. Anthropological research and theory can make a significant contribution by exploring this apparent opposition. For 
example, I (Urban 2016: 334-36, based on results in Urban et al. 2007) looked at the perceived similarities and differences between the faces, the grills and headlights of sports-utility vehicles as they change over time. I found that the changes introduced by manufacturers resembled the changes being made by other manufacturers, which means that manufacturers were copying each other. However, companies also made sure to introduce differences in the copy so that the corporation-specific characteristics of the commodity could be readily detected. The interest of consumers in some commodities as opposed to others, including the affective charge those commodities seem to have, may also be linked to the similarities and differences mapped out by the field of inter-corporate relations as it evolves over time, thereby beginning to address the kinds of questions raised by Richard Wilk and Eric Arnould (2016) about diffusion and demand.

Maintaining the distinctiveness of a corporation's commodities, despite the ease of inter-corporate copying, depends in some measure on the corporation's legal status and, in particular, on its capacity to own intellectual property, including patents and copyrights (see Coombe 1998; Moore 2003). A number of anthropological studies deal with the relationship between the legal capture of the cultural characteristics of a corporation's commodities and the status of small-scale producers in other countries, for example Kedron Thomas's (2016) research on the 'criminalization of brand piracy' by independent clothing producers in Guatemala and Constantine Nakassis's $(2012,2013,2016)$ work on brand counterfeiting in South India. The legal capture of cultural flow has also come under scrutiny in the pharmaceutical industry, where drugs can be readily reverse engineered, which means that what is needed to produce them can be figured out by analysing the finished product. An important instance of this is Brazil's successful struggle with multinational pharmaceutical companies to reduce the price of HIV medications (Biehl 2004). While anthropologists have been especially concerned with the relationship between the legal corporation's commodities and the copies produced extra-legally, the copying and differentiating relationship among legal producers themselves promises to provide insight into the nature of demand itself, since that relationship appears to map the social fields in which demand unfolds.

Whether the similarities between commodities produced by two different companies are legal or not depends on recognition of the producers by the state. That is, it depends on state recognition of the corporation in the anthropological sense as a legal corporation. Examination of inter-corporate copying, with or without the introduction of significant difference, thus raises theoretical questions about the nature of community in the modern world. The legitimate use of force today is understood as the province only of states, with corporations engaging instead in state-sanctioned competition in the marketplace. At the same time, and as I noted previously, modern business corporations grew out of early chartered joint-stock companies, and originally those were arms of the state and, in many cases, they had their own armies and routinely employed military force in co-operation with state armies (e.g. the British East India Company, Bryant 1978). Of course, major companies these days employ security services, and the distribution of the use of 
coercive force between states and private corporations is an empirical question. However, corporate security forces are not authorised to use coercion in policing the copying that goes on between corporations with regard to the commodities that they produce or even with regard to their internal culture. Enforcing the legal limits of inter-corporate cultural borrowing falls upon the state. Anthropologists can play a role in assessing how variations around the world in state regulatory and enforcement regimes, as well as in broader local, national and regional culture, affect the fields of commodities in which the forces of interest (as demand and desire) operate. What commodities are legally available on markets? What commodities circulate in extra-legal environments? In what measure is the internal culture of a corporation shaped by the legality or illegality of inter-corporate copying?

\section{The future}

Economic theory has approached the inner worlds of business corporations and their relations with the external world from the starting point of individual rational actors. For political economists, drawing inspiration from the Marxist tradition, the starting point is domination, exploitation and power relations. While ethnographic research justifies these approaches in some measure, a third perspective, the one developed in this chapter, is a possible course for future research in economic anthropology. That is to examine corporations as culture-bearing social groups, which means to examine them as communities. This in turn leads to the possibility of theorising the relations between corporations and other collective and individual actors, including families and households, and also states and regulatory bodies, as aspects of large-scale community that can be understood as bearing complex and dynamic cultures.

From this perspective, economic theory appears as part of circulating metaculture (Urban 2001) that can diffuse through the world, penetrating the boundaries of corporations and other collective social actors and shaping the activity within them (Mackenzie et al. 2007). In what measure do business corporations conform to models contained in economic theory? In what measure do they operate like noneconomic communities, built around internal cultural practices, rituals and symbols, as well as non-economic values? Similarly, political-economic perspectives also circulate as metaculture, especially in such arenas as union organising, strikes and broader antipathy to capitalism and capitalist practices. In what measure do these circulating ideas and normative orientations help to shape community in the modern world?

From the starting point of for-profit corporations as forms of communal association that contribute to broader bases of markets and communities, the commodities that they produce appear as congealed bits of culture that participate in and help to shape social and cultural fields (Bourdieu 1984). From this perspective, demand for commodities amounts to the desire for the culture that those commodities carry. Simultaneously, the ease of copying, a form of cultural motion, contributes 
to the creation of a broader culture that has patterns that shift over time. A task for economic anthropology is to chart those patterns and investigate the regulatory and power relations that shape them and their changes. We can even peer into the future and try to sketch the kinds of community that might be born out of our present culture and social formations.

\section{References}

Bailey, F.G. 2003. The Saving Lie: Truth and Method in the Social Sciences. Philadelphia: University of Pennsylvania Press.

Bashkow, Ira 2014. Afterword: What kind of person is the corporation? PoLAR 37 (2): 296-307.

Benson, Peter 2014. Corporate paternalism and the problem of harmful products. PoLAR 37 (2): 218-30.

Biehl, João 2004. The activist state: Global pharmaceuticals, AIDS and citizenship in Brazil. Social Text 22 (3): 105-32.

Bössmann, Eva 1981. Weshalb gibt es Unternehmungen? Der Erklärungsansatz von Ronald H. Coase. Journal of Institutional and Theoretical Economics 137: 667-74.

Bourdieu, Pierre 1984. Distinction: A Social Critique of the Judgment of Taste. Richard Nice, trans. Cambridge, MA: Harvard University Press.

Boyer, Madeline 2018. Working Alone, Together: Coworking, Community, and Cultural Flow. PhD Dissertation, Department of Anthropology, University of Pennsylvania.

Braudel, Fernand 1982. Civilization and Capitalism, 15th-18th Century, Vol. II: The Wheels of Commerce. Siân Reynolds, trans. New York: Harper \& Row.

Bryant, Gerald 1978. Officers of the East India Company's army in the days of Clive and Hastings. The Journal of Imperial and Commonwealth History 6 (3): 203-27.

Business Historical Society 1929. The oldest joint-stock company. Bulletin of the Business Historical Society 3 (1): 7-8.

Callon, Michel 1998. Introduction: The embeddedness of economic markets in economics. In The Laws of the Markets (ed.) M. Callon, pp. 1-57. Oxford: Blackwell Publishers.

Chamberlin, Edward 1933. The Theory of Monopolistic Competition: A Re-orientation of the Theory of Value. Cambridge, MA: Harvard University Press.

Coase, Ronald H. 1937. The nature of the firm. Economica 4 (16): 386-405.

Comaroff, John L. and Jean Comaroff 2009. Ethnicity, Inc. Chicago: University of Chicago Press.

Coombe, Rosemary J. 1998. The Cultural Life of Intellectual Properties: Authorship, Appropriation, and the Law. Durham, NC: Duke University Press.

Cooper, Matthew 1987. Relations of modes of production in nineteenth century America: The Shakers and Oneida. Ethnology 26 (1): 1-16.

Davis, John P. 2000 (1905). Corporations: A Study of the Origin and Development of Great Business Combinations and of Their Relation to the Authority of the State. Two volumes. Washington, DC: Beard Books.

Deal, Terrence E. and Allan A. Kennedy 1982. Corporate Cultures: The Rites and Rituals of Corporate Life. Reading, MA: Addison-Wesley.

Dunn, Malcolm H. 1992. Firms, markets and hierarchies: A critical appraisal of Ronald Coase's contribution to the explanation of the 'nature of the firm'. Jahrbuch für die Ordnung von Wirtschaft und Gesellschaft 43: 193-204.

Eklund, Robert B., Jr. and Robert D. Tollison 1980. Mercantilist origins of the corporation. The Bell Journal of Economics 11 (2): 715-20.

Ensminger, Jean 1990. Co-opting the elders: The political economy of state incorporation in Africa. American Anthropologist 92 (3): 662-75. 
Ensminger, Jean 1992. Making a Market: The Institutional Transformation of an African Society. New York: Cambridge University Press.

Fama, Eugene 1965. The behavior of stock market prices. Journal of Business 38 (1): 34-105.

Fisher, Melissa S. 2012. Wall Street Women. Durham, NC: Duke University Press.

Fortes, Meyer 1969. Kinship and the Social Order: The Legacy of Lewis Henry Morgan. Chicago: Aldine Publishing.

Foster, Robert 2014. Corporations as partners: 'Connected capitalism' and the Coca-Cola Company. PoLAR 37 (2): 246-58.

Foster, Robert 2017. The corporation in anthropology. In The Corporation: A Critical Multidisciplinary Handbook (eds) Grietje Baars and André Spicer, pp. 111-33. New York: Cambridge University Press.

Ganti, Tejaswini 2014. Neoliberalism. Annual Review of Anthropology 43: 89-104.

Garsten, Christina 1994. Apple World: Core and Periphery in a Transnational. Stockholm studies in social anthropology 33. Stockholm: Department of Social Anthropology, Stockholm University.

Garsten, Christina and Adrienne Sörbom 2019. His master's voice: Conceptualizing the relationship between business and the World Economic Forum. Journal of Business Anthropology 8 (1). (forthcoming)

Guillet, David 2001. Reconsidering institutional change: Property rites in northern Spain. American Anthropologist 102 (4): 713-25.

Hamada, Tamoko 1991. American Enterprise in Japan. Albany: State University of New York Press.

Harvey, David 2005. A Brief History of Neoliberalism. New York: Oxford University Press.

Haxhi, Ilir and Hans van Ees 2010. Explaining diversity in the worldwide diffusion of codes of good governance. Journal of International Business Studies 41 (4): 710-26.

Heckscheler, E.F. 1934. Mercantilism. Two volumes. Mendel Shapiro, trans. London: George Allen and Unwin.

Ho, Karen 2009. Liquidated: An Ethnography of Wall Street. Durham, NC: Duke University Press.

Holmes, Douglas R. 2009. Economy of words. Cultural Anthropology 24 (3): 381-419.

Kim, Choong Soon 1992. The Culture of Korean industry. Tucson: University of Arizona Press.

Krause-Jensen, Jakob 2010. Flexible Firm: The Design of Culture at Bang E Olufsen. New York: Berghahn Books.

Kunda, Gideon 1995. Engineering culture: Control and commitment in a high-tech corporation. Organization Science 6 (2): 228-30.

Licht, Walter 2014. The rise and embedding of the corporation: Considerations for American democracy and citizenship. In Corporations and Citizenship (ed.) Greg Urban, pp. 143-64. Philadelphia: University of Pennsylvania Press.

Mackenzie, Donald, Fabian Muniesa and Lucia Siu (eds) 2007. Do Economists Make Markets? On the Performativity of Economics. Princeton, NJ: Princeton University Press.

Maine, Henry Sumner, Sir 1917 (1861). Ancient Law: Its Connection with the Early History of Society, and its Relation to Modern Ideas. London: Dent.

Manning, Paul 2010. The semiotics of brand. Annual Review of Anthropology 39: 33-49.

Marx, Karl 1990 (1867). Capital: A Critique of Political Economy, Vol. 1. Ben Fowkes, trans. London: Penguin.

Moore, Robert E. 2003. From genericide to viral marketing: On 'brand'. Language and Communication $23(3): 331-57$.

Nakassis, Constantine 2012. Counterfeiting what? Aesthetics of brandedness and BRAND in Tamil Nadu, India. Anthropological Quarterly 85 (3): 701-22.

Nakassis, Constantine 2013. The quality of a copy. In Fashion India: Spectacular Capitalism (ed.) Tereza Kuldova, pp. 142-65. Oslo: Akademika.

Nakassis, Constantine 2016. Doing Style: Youth and Mass Meditation in South India. Chicago: University of Chicago Press. 
North, Douglass C. 1990. Institutions, Institutional Change and Economic Performance. New York: Cambridge University Press.

North, Douglass C. and Robert P. Thomas 1973. The rise of the Western world. New York: Cambridge University Press.

Oliveira, Pedro 2013. People-Centered Innovation: Becoming a Practitioner in Innovation Research. Columbus, OH: The Educational Publisher/Biblio Publishing.

Orr, Julian E. 1996. Talking about Machines: An Ethnography of a Modern Job. Ithaca: Cornell University Press.

Ouchi, William 1981. Theory Z: How American Business Can Meet the Japanese Challenge. Reading, MA: Addison-Wesley.

Pascale, Richard Tanner and Anthony G. Athos 1981. The Art of Japanese Management: Applications for American Business. New York: Simon and Schuster.

Prentice, Michael M. 2015 Managing intertextuality: Display and discipline across documents at a Korean firm. Signs and Society 3 (S1): S70-94.

Radcliffe-Brown, A.R. 1952. Structure and Function in Primitive Society. London: Routledge and Kegan Paul.

Røyrvik, Emil A. 2013. Incarnation Inc.: Managing corporate values. Journal of Business Anthropology 2 (1): 9-32.

Rydberg, Sven 1979. Stora Kopparberg: 1000 Years of an Industrial Activity. Stockholm: Gullers International $\mathrm{AB}$.

Sandler, Jen and Rita Thedvall (eds) 2017. Meeting Ethnography: Meetings as Key Technologies of Contemporary Governance, Development, and Resistance. New York: Routledge.

Schwartzman, Helen B. 1989. The Meeting: Gatherings in Organizations and Communities. New York: Plenum Press.

Smith, Adam 1994 (1776). An Inquiry into the Nature and Causes of the Wealth of Nations. New York: Random House.

Stull, Donald D. 2017. Cows, pigs, corporations, and anthropologists. Journal of Business Anthropology 6 (1): 24-40.

Thomas, Kedron 2016. Regulating Style: Intellectual Property Law and the Business of Fashion in Guatemala. Oakland: University of California Press.

Urban, Greg 2001. Metaculture: How Culture Moves Through the World. Minneapolis: University of Minnesota Press.

Urban, Greg 2015. Symbolic force: A corporate revitalization video and its effects. Signs and Society 3 (S1): S95-124.

Urban, Greg 2016. Corporations in the flow of culture. Seattle University Law Review 39 (2): 321-51.

Urban, Greg and Kyung-Nan Koh 2013. Ethnographic research on modern business corporations. Annual Review of Anthropology 42: 139-58.

Urban, Greg, Ernest Baskin and Kyung-Nan Koh 2007. 'No carry-over parts': Corporations and the metaculture of newness. Suomen Antropologi 32 (1): 5-19.

Venkatraman, N., Lawrence Loh and Jeongsuk Koh 1994. The adoption of corporate governance mechanisms: A test of competing diffusion models. Management Science 40 (4): 496-507.

Watson, James L. (ed.) 1997. Golden Arches East: McDonald's in East Asia. Stanford: Stanford University Press.

Weber, Max 1968 (1925). Economy and Society. Guenther Roth and Claus Wittich, eds. Berkeley: University of California Press.

Wilf, Eitan 2015. Ritual semiosis in the business corporation: Recruitment to routinized innovation. Signs and Society $3\left(\mathrm{~S}_{1}\right)$ : $\mathrm{S}_{13}-40$.

Wilk, Richard R. and Eric J. Arnould 2016. Why do the Indians wear Adidas? Or culture contact and the relations of consumption. Journal of Business Anthropology 5 (1): 6-36. 